\title{
Elena Faur
}

Institutul de Lingvistică şi Istorie Literară 'Sextil Puşcariu'

\section{Integral Semantics and Conceptual Metaphor: Rethinking Conceptual Metaphor Within an Integral Semantics Framework}

\begin{abstract}
The paper focuses, on the one hand, on two theoretical problems of Conceptual Metaphor Theory: namely, the cognitive status and the creative dimension of the conceptual metaphors; on the other, it aims at approaching some descriptive findings from Conceptual Metaphor Theory within the perspective of Coseriu's semantics. Over the past years, the universalist claim of pre-linguistic embodiment via image schemas has been subject to much criticism. Recent attempts to simply situate conceptual metaphors within a social and cultural context did not bring the expected results. Therefore, the need for a radical breakthrough from the old conceptual and theoretical framework of Lakoff and Johnson's Conceptual Metaphor Theory became urgent. The reconstruction of cognitive science on phenomenological and hermeneutical bases is on the way to being pursued within the rising of the third generation of cognitive science. It will certainly represent a major advance for bridging the gap between cognitive science and other traditions of research, such as integral semantics.
\end{abstract}

Keywords: conceptual metaphor, image schema, embodiment, creativity, intersubjectivity, linguistic sign, (symbolic) representation, metaphorical meaning, meaning proper, designation, knowledge of things, context of culture.

\section{AN ATTEMPT TO BRIDGE THE GAP BETWEEN COGNITIVE SEMANTICS} \section{AND INTEGRAL LINGUISTICS}

This paper aims to demonstrate, on the one hand, how Integral Semantics (IS) can help Cognitive Semantics (CS) solve some conflicting positions regarding Conceptual Metaphor Theory (CMT); and, on the other, to show how both can turn their most important findings into solid accomplishment. My quest for integrating these theories will mainly be pursued within the field of restructuring work done by the third generation of cognitive science. ${ }^{1}$ How can these theories be brought together? IS seems to

\footnotetext{
${ }^{1}$ It is well known that the demarcation between generations of cognitive science varies, to some degree, between authors, relative to the criteria used for judging the unity of the field within the cognitive science paradigm. My understanding is more sympathetic to Zlatev's $(2007,2008$ a) and Sonesson's (2009) position than to Thompson's (2007). I refer to the third generation of cognitive science as the relatively recent research drive that attempts systematically to reconstruct and rethink the theoretical and conceptual foundations of cognitive science on the strength of concepts such as subjectivity, intersubjectivity, consciousness, and linguistic sign. Although the first signs of a new generation of cognitive science came from works developed in relative isolation, recently a few scholars have unified their efforts and consolidated a distinct perspective called

Address for correspondence: Academia Română, Filiala Cluj-Napoca; Institutul de Lingvistică şi Istorie Literară ,Sextil Puşcariu' - Str. Emil Racoviţă nr. 19-21, 400165 Cluj-Napoca, România, elena_faur@inst-puscariu.ro; faur.elenacarmen@gmail.com.
} 
provide the broadest conceptual and theoretical framework for a comprehensive, coherent, integrational matrix of the current directions in linguistics (see e.g. Zlatev 2011). CMT can find its specific place within IS: namely, at the universal level of speaking in Coseriu's matrix (see below). At the same time, IS can, within its overall perspective, value several discoveries from CS in the field of 'metaphorology'.

\begin{tabular}{|l|l|l|l|l|}
\hline \multicolumn{5}{|c|}{ Points of view } \\
\hline $\begin{array}{l}\text { Levels of } \\
\text { language }\end{array}$ & $\begin{array}{l}\text { Activity } \\
\text { Enérgeia }\end{array}$ & $\begin{array}{l}\text { Knowledge } \\
\text { Dynamis }\end{array}$ & $\begin{array}{l}\text { Product } \\
\text { Ergon }\end{array}$ & Content \\
\hline Universal & Speaking in general & $\begin{array}{l}\text { Elocutional } \\
\text { knowledge }\end{array}$ & $\begin{array}{l}\text { Totality of } \\
\text { utterances }\end{array}$ & Designation \\
\hline Historical & $\begin{array}{l}\text { Concrete particular } \\
\text { language }\end{array}$ & $\begin{array}{l}\text { Idiomatic } \\
\text { knowledge }\end{array}$ & $\begin{array}{l}\text { (Abstracted } \\
\text { particular } \\
\text { language) }\end{array}$ & Meaning \\
\hline Individual & Discourse & $\begin{array}{l}\text { Expressive } \\
\text { knowledge }\end{array}$ & Text & Sense \\
\hline
\end{tabular}

Table 1: Coseriu's matrix, adapted from Coseriu (1985).

There are at least three main points at which the two, seemingly incompatible, frameworks - CS and IS - can be brought together. (1) Both CS and IS place metaphor in the genus proximum of human creative-imaginative activities. (2) Both types of semantics view metaphor as a cognitive category of thinking and - with some qualifications - human language. (3) Both understand metaphorical knowledge as knowledge based on images.

Apart from such convergences, the solutions offered by these approaches could not seem more different - even though they start from a common, broad sense in which metaphor can be seen as the creation of new imagistic semantic contents in everyday speaking, one of the usual means of speaking by relating to things, events, or aspects of one's experience. However, unlike Coseriu who - as early as 1952 (1985 [1952]; see also Borcilă, 2003) - situated 'metaphorical creation' in an enlarged sense within the cognitive medium of language, CS views metaphor as a phenomenon that creates new cognitive contents, or conceptual domains of thought, within the framework of mental spaces that are prior to, and independent of, language function. ${ }^{2}$ Any attempt to bridge the gap between these different 'cognitive' perspectives necessarily involves a more basic consideration at the level of the conceptual backgrounds of the theories under consideration.

cognitive semiotics (see Zlatev 2012). This perspective integrates results from cognitive science and semiotics to create an adequate framework for the human and social sciences (see Sonesson 2009). The third-generation systematic reconstruction of cognitive science has opened the path to a promising dialogue between integral and cognitive linguistics by its systematic examination of the core concept of intersubjectivity, involved in both the intersubjective constitution of the world and the emergence of shared linguistic meanings (see Zlatev, Racine, Sinha \& Itkonen 2008, where this concept is approached from several perspectives).

${ }^{2}$ The crucial difference is connected with a larger, more fundamental quarrel regarding the role attributed to the 'language faculty' in the constitution and functioning of the human mind. Coseriu's conception is obviously based on a Humboldtian platform, according to which language - in its essence - is not simply instrumental but constitutive of human mind and consciousness. 


\section{THE CONCEPTUAL METAPHOR MODEL IN COGNITIVE SEMANTICS}

\subsection{Lakovian theory and its critiques}

The new conceptualization of metaphor proposed by Lakoff and Johnson (2003 [1980], 1999) is built on the idea that metaphors are not linguistic expressions or 'figurative elements of speech' but rather conceptual structures - conceptual metaphors ${ }^{3}$ - that can be identified at a level prior to their manifestation in language. Furthermore, it is claimed that conceptual metaphors have a decisive role in structuring and defining one's ordinary conceptual system. Metaphorical expressions such as we are close friends or we've been close for years, but we've beginning to drift apart are considered surface manifestations of a single conceptual metaphor: INTIMACY IS CLOSENESS.

Lakoff and Johnson understand metaphor as a layer of conceptual content, whose function is to produce 'new understandings [of things] and ... new realities' (Lakoff \& Johnson 2003 [1980]: 235). As far as the functional principle of these conceptual metaphors is concerned, the new metaphorical content is produced by mapping or 'projecting' an image-schematic structure of experiential content from a source domain onto a target domain. The connection of the two conceptual domains is not arbitrary. It does not occur in the absence of, or separately from, the contents of pre- or extra-linguistic experience but is motivated by the metaphorical elaboration of image-schematic pre-conceptual structures.

Enthusiastically welcomed by many researchers in the field - while subsequently subject to criticism (see e.g. Rakova 2002, Haser 2005) - $\mathrm{CMT}^{4}$ filled a gap that was profoundly felt in traditional metaphorology, dealing with the way structures of experience participate in the production and understanding of metaphorical speaking: i.e., in the creation of designative metaphorical contents.

More than three decades since its original formulation, as a result of much empirical research the theory has undergone numerous adjustments, which have led to increasing refinement of its conceptual apparatus. In spite of the undeniable descriptive avenues opened by CMT, theoretical problems relating to both the status of metaphors and the cognitive aspect of the theory proved to be insufficiently explored and questioned. It is safe to say that the fate of this model of conceptual metaphor largely depends on solving these theoretical problems (Borcilă 1997; see also Faur forthcoming).

The belief that metaphor is a conceptual mental phenomenon prior to, and independent from, the metaphorical expression as such is shared by nearly all cognitive semanticists. From this perspective, 'metaphorical speaking ${ }^{5}$ is nothing but an epiphenomenon in relation to metaphorical thought: a

\footnotetext{
${ }^{3}$ Metaphoric concepts in the first formulation of the theory (Lakoff \& Johnson 1980).

${ }^{4}$ Since 1980, CMT has passed through several versions due to its difficulties solving the problem of the creation of new metaphorical contents. For the different versions of CMT, see Section 3.3.

${ }^{5}$ Lakoff and Johnson (2003 [1980]) do not refer to the traditional linguistic distinctions between language (faculty and activity), langue (linguistic system), and speech (individual utterances). Lakoff and Johnson's distinction between metaphorical thought and metaphorical speaking principally serves to demonstrate that metaphor is not confined to language (and, within this realm, is not a matter of stylistic flourish) but is
} 
'surface manifestation'. The immediate consequence of postulating such a conceptual level is, as A. Barcelona notes (2000: 2), that the 'faculty of language' becomes a mere 'reflection' or 'specialization' of 'general cognitive abilities'. Cuenca and Hilferty (1999) consider the denial of language's functional autonomy a 'fundamental principle' of cognitive linguistics (CL), according to which 'language is not an autonomous faculty' but subordinate to - or at least integrated with - the

other 'human cognitive abilities' (Cuenca \& Hilferty 1999: 181). ${ }^{6}$ Borcilă (2003) argues that the separation of the two levels in $\mathrm{CL}$ - the conceptual and the linguistic - and especially the reduction of language to the level of 'expression' and the failure to acknowledge the primordial cognitive function of language undermine the project's goal from the very beginning: the goal of explaining the creation of new metaphorical contents in everyday speaking.

Few studies have tackled head on the problematic aspects that arise when surgically separating the conceptual and linguistic levels of metaphor. Haser (2005) has been one of the most outspoken critics of the conceptual metaphor model. She noticed how, when explaining conceptual metaphors, the starting point for cognitive semanticists is always metaphorical speaking. Naturally, with this in mind, she wondered if metaphoric concepts determine the emergence of linguistic expressions or vice versa. The alleged primacy of conceptual metaphor in relation to metaphorical speaking conflicts with the observation that the model cannot demonstrate the presence of conceptual metaphor in the absence of metaphorical linguistic expressions in which conceptual metaphor is supposed to be crystallized. This causes Haser (2005: 147) to question the legitimacy of the jump from thought to language - or vice versa, from language back to thought. However, with no intention to minimize the significance of her work, I believe she does not solve the problem in a satisfactory manner. On a closer look, it is unclear how connections between the conceptual and linguistic levels can be established without providing a different operational framework.

\subsection{The sociocultural situatedness of conceptual metaphors}

Ever since the first formulation of Lakoff and Johnson's CMT within experientialist semantics (Lakoff \& Johnson 1980) and afterwards within embodiment theory (Lakoff \& Johnson 1999), it has been claimed that metaphorical thinking makes use of recurrent schematic-imagistic patterns of one's embodied experience. More precisely, proponents of CMT argue that one's capacity for conceptual metaphor is linked to one's embodied, pre-verbal experience, based on the mapping of 'experiential structure from the "imagistic" realm of sensory-motor experiences to non-imagistic ("abstract") ones' (Hampe 2005: 2). For example, the embodied experience of containment is central to understanding both linguistic expressions such as your argument doesn't have much content or your argument is vacuous and the underlying conceptual metaphor AN ARGUMENT IS A CONTAINER. In addition,

cognitively important. Yet their distinction between the two levels, of thought and language, is, to some extent, analogous to Saussure's distinction between langue and parole (speech) (see Section 3.3).

6 'El lenguaje no es una facultad autónoma, sino que se relaciona con los otras habilidades cognitivas humanas'. 
Lakoff and Johnson claim that experience is 'never merely a matter of having a body of a certain sort; rather, every experience takes place within a vast background of cultural presuppositions': i.e., 'all experience is cultural through and through..., we experience our "world" in such a way that our culture is already present in the very experience itself' (Lakoff \& Johnson 2003 [1980]: 57). However, in both Lakoff and Johnson's experientialist semantics and their embodiment theory, it remained a highly controversial issue ${ }^{7}$ how universal pre-linguistic embodiment via image-schemas ${ }^{8}$ could account for sociocultural embeddedness. ${ }^{9}$. Recently, the claim for the universalism of conceptual metaphor has been debated within the context of an increasingly amount of research. Over the past few years, researchers have argued for the need to link the body to culture and described the sociocultural situatedness of image-schemas: that is, the embodiment that grounds conceptual metaphor (Gibbs 1999; Kimmel 2005, 2008; Yu 2008a, 2008b; Violi 2008; Zinken, Hellsten \& Nerlich 2008).

Within a psychological framework, Gibbs (1999) criticizes the cognitive linguists' and cognitive psychologists' view of metaphor as the conceptual structure of thought, warning against the solipsism imminent in their theory. Using an appropriate metaphor, Gibbs summons cognitive scientists 'to move' metaphor 'out of our heads' 'into the embodied and public world'. He stresses the cultural dimension of cognition, arguing that image schemas are not universal patterns but rather have a strong cultural component. He offers illuminating examples showing that culture is not something added to the physical interaction of body with world ${ }^{10}$; rather experience itself is culturally constituted. $\mathrm{He}$ proposes a perspective on embodied metaphors as shared representations, within a cultural community, that play a pivotal role in both language and thought. The far-reaching, fundamental principle Gibbs brings forward is 'that cognition arises, and it is continually re-experienced, when the body interacts with the cultural world' (Gibbs 1999: 162; emphasis added).

In the same vein as Gibbs, Yu (2008a; 2008b) demonstrates that, if the body is 'a potential universal source domain for metaphorical mappings from bodily experiences onto more abstract and subjective domains' (Yu 2008b: 250), then cultural models constitute the filter of bodily experience,

\footnotetext{
${ }^{7}$ The concept of image schema as well as the meta-theoretical concept of embodiment have been subject to much critique, because they lack the very characteristics that would prove their phenomenological character: intersubjectivity, accessibility to consciousness, and the possibility to be linked to language (Zlatev 2007). The issues have been discussed within two recent volumes: (Haser 2005) and (Ziemke, Zlatev \& Frank 2007). Perhaps the most vehement critiques of Lakoff and Johnson's concepts are raised from within the third generation of cognitive science: see (Zlatev 2005, 2007, 2008a, 2010, 2011; Itkonen 2006, 2008; Sonesson 2007, 2009).

${ }^{8}$ Both image schema and embodiment are ambiguous concepts in the cognitive science literature: one cannot find a unified notion of either one.

${ }^{9}$ The term sociocultural situatedness (or sociocultural embeddedness) makes reference to the work of a group of cognitive researchers who criticize Lakoff and Johnson's notion of embodiment as isolated from any interaction with social and cultural context. The concept 'denotes the way(s) in which individual minds and cognitive processes are shaped by their being together with other embodied minds, i.e., their interaction with social and cultural structures, such as other agents, artefacts, conventions, etc., and more particularly..., with language itself' (Frank 2008: 1).

${ }^{10}$ Otherwise, such interaction would give rise to universal patterns of thinking and reasoning.
} 
setting up perspectives from which each experience is viewed. Yu (2008b) analyzes the complex metaphors DIGNITY IS FACE and PRESTIGE IS FACE in Chinese to show how the bodily basis of the 'image' can motivate a metaphor, but the 'actual selection' of it largely depends on its cultural basis. Moreover, he proves that 'culture serves as a filter that only allows certain bodily experiences to pass through so that they can be mapped onto certain target-domain concepts' (Yu 2008b: 249).

Kimmel (2005) raises a much stronger critique of the universality claim for image schemas 'as the grounding of metaphoric mappings in primary scenes'. He argues that cognitive semanticists' 'ontology and... methodology of image schema research remains grounded in mutually strengthening biases which are not exactly congenial with a socio-cultural view' (Kimmel 2005: 288). On the one hand, this happens because image schemas - due to their supposed universal pre-linguistic embodiment - are understood as 'developmental universals'. On the other hand, since 'embodiment is rooted in the kinaesthetic experiences in space', there is no place for culture to shape the body - only the opposite (Kimmel 2005: 288). Kimmel demonstrates that, from the perspective of image schema acquisition, it is necessary to take into account the dialectical relationship between body and culture. In his account, image schemas are not universal patterns: they are 'learned' and permanently 'refined' in 'culturally recurrent settings'. He redefines image schemas as 'tools for situated cognition and action' (Kimmel 2005: 305). In response to Johnson's understanding of image schemas, Kimmel proposes a 'balanced view'. He demonstrates 'how discourse, ritual, and material culture shape image schemas', and he tries to overcome the 'tendency to unidirectionally theorize how image schemas shape discourse' (Kimmel 2005: 299). As a direct consequence for this paper, his sociocultural perspective opens a horizon in which language begins to regain its proper place in human cognition. He insists that "we need to develop frameworks... that capture how image-schematic metaphors, for example, are doubly constrained by embodied experiences and by cultural ideology' (Kimmel 2005: 299; emphasis original).

Although all these researchers signalled the urgent need to re-evaluate concepts at the heart of Lakoff and Johnson's CMT, they were yet not been prepared for a radical change in the conceptual and theoretical framework. However, it became clear that progress toward a radical breakthrough could not be achieved through the extension or relaxation of the core concepts of embodiment theory (Borcilă forthcoming). The major reason behind this failure was the lack of systematically developed notions of subjectivity, intersubjectivity, consciousness, and - especially - linguistic sign. Too, there was no coherent framework able to explain the formative role of language and culture in shaping the body or the dialectic relationship between culture and body. I think that such a systematic interdisciplinary framework is emerging in the process of the conceptual reconstruction of cognitive science proposed by the third generation (see Section 2.1).

Basing his work on the new conceptual framework and its achievements, Zlatev characterizes the world $^{11}$ in which human beings are embedded as the universe of discourse $e^{12}$ and the embodiment ${ }^{13}$ at

\footnotetext{
${ }^{11}$ In his theory of embodiment of meaning, Zlatev (2009b) distinguishes four worlds according to four kinds of embodiment, the subject involved in each world, and the subject's internal value system.
} 
this level as extended embodiment (2009a, 2009b). This world consists of "cultural beliefs, myths, scientific theories, political ideologies, novels, poems, internet forums, blogs etc. which are made possible by language' (Zlatev 2009b: 19). The universe of discourse is extended to include the inferior levels and is largely based on language and culture; but these, in turn, are based on the consciousness of the lived body, and ultimately in autopoiesis of the living. Zlatev systematically pleads for a sociocultural perspective on embodiment, built on phenomenological and hermeneutic bases. $\mathrm{He}$ acknowledges the linking of 'the bodily experience to the wider world of culture' (Zlatev 2009b: 155), pointing out the important role of language in grounding culture and the way culture, in turn, shapes the body. In my view, this acknowledgement of the functional autonomy of language and its role in human cognition represents a major advance in relation to the previous generation.

\subsection{Some remarks on the first conceptual level (the source domain) for metaphor}

One of the basic assumptions of CMT is the principle of image-schema projection, from the preconceptual level onto the conceptual level and within the conceptual level itself: from concrete to abstract - metaphorical - concepts. Referring to the first conceptual level - the source domain for the metaphor - one must remember how Lakoff (1987) defines the appropriate concepts and categories. ${ }^{14}$ According to Lakoff (1987: 279), 'basic-level and image-schematic concepts are directly meaningful concepts..., [having an] internal structure'. ${ }^{15}$ The conceptual content is meant to be formed by 'a rich mental image, characterizing the overall shape' of the object, and by 'a schematic structure' formed from different image-schematic structures: e.g., the concept of MAN 'is structured as having an UPDOWN organization; it is structured as a container having an INSIDE and an OUTSIDE' (Lakoff 1987: 280). Lakoff acknowledges that these schematic structures do not exhaustively structure the concept of MAN, even though he does not make clear what else the conceptual content of MAN can imply. He claims moreover that these concepts are 'symbolic structures' and that they can build complex cognitive models structured by image schemas. He argues that, for every concept, one finds a corresponding category in any given domain of discourse. Linguistic expressions get their meaning either by 'being associated directly' with 'idealized cognitive models' or by 'having elements of the idealized cognitive models' (Lakoff 1987: 291).

Coseriu (2000 [1990]) heavily criticizes prototypes semantics. In one of his lectures delivered in Cluj-Napoca, Coseriu (1999) concludes that Lakoff's CS cannot avoid his objection to prototypes semantics. In both cases, Coseriu criticizes the principle of 'inference of the general' ${ }^{16}$, showing that,

\footnotetext{
${ }^{12}$ The concept of universe of discourse originates in logical semantics. Zlatev follows Sinha's (2004) usage.

${ }^{13}$ The four levels of meaning embodiment proposed by Zlatev (2009b) and developed within an evolutionary framework are biological, phenomenological, significational (sign-based), and extended embodiment.

${ }^{14}$ See also (Lakoff \& Johnson 1999, De Oliveira \& Bittencourt 2008).

${ }^{15}$ A few pages after stating that every concept has an internal structure, Lakoff writes (1987: 279) that 'every concept either has internal structure or it does not'. He calls the concept with no internal structure 'primitive' and the one with internal structure 'complex'.

${ }^{16}$ The discussion of 'robin' as the prototype of 'bird' is widely known. Coseriu argues that, in the case of the
} 
under closer scrutiny, prototype semantics is no longer " semantic" theory proper'; nor is it 'cognitive': it is, at best, a 'semantics of things' and the 'cognitive dimension' named by these semanticists relates to 'designated objects and to the knowledge related to things' but not to 'linguistic meaning' or 'knowledge of linguistic meaning' (Coseriu 2000 [1990]).

Two central characteristics of - mainstream - CL expose it to the same objections Coseriu addresses to Lakoff. The first characteristic - also discussed by Cuenca and Hilferty - concerns the way 'cognitive linguistics proposes a direct equivalence between linguistic meaning and conceptualization' (Cuenca \& Hilferty 1999: 185; my translation ${ }^{17}$ ). The result is that, 'as it happens in conceptualization, it happens in the case of linguistic meaning as well: it cannot be understood without being contextualized' (Cuenca \& Hilferty 1999: 185; my translation ${ }^{18}$ ). Taking their comment as a starting point and extending Coseriu's main objection, I would claim that most of cognitive linguistics "completely ignores... linguistic knowledge represented by the meanings of a particular language, and only considers their application in designation, thus muddling up the linguistic knowledge of meanings and the knowledge speakers/hearers have of the objects ("things", "events", etc.) in the external world' (Coseriu 2000 [1990]: 41). ${ }^{19}$

The second characteristic relates to taking over the prototype semantics within the framework of lexical semantics ${ }^{20}$ and other disciplines in CL. CL bases itself on the Lakoff approach to semantics, and, therefore, states that linguistic meaning is centered around a prototype: i.e., a central sense. Unlike the Lakoff approach, CL distinguishes however the 'intensional' from the 'extensional' level of linguistic meaning. Nevertheless, the problem persists in how the intensional level is characterized. ${ }^{21}$

In the reminder of this section, I will refer with no distinction to both characteristics and present my objection in three steps. ${ }^{22}$ First, it is known that, as an 'usage-based' approach to semantics (e.g., Geeraerts 1993, 1997, 2000, 2010) or grammar (e.g., Taylor 1999), CL is mainly interested in the way linguistic meaning is understood and how it varies between different contexts of discourse. CL views the relation between conceptual content ('concept') and extra-linguistic reality as the primary

supposed constitution of the prototype for 'bird' through 'analogical extension', 'the prototype of "bird" must already be "bird", and not simply "robin"', because 'what is added per analogiam is not "something like a robin" or "examples of a robin", but another example of "bird"'. What matters 'is not the extension from the example "robin" [to "sparrow", "swallow", or "blackbird"], but the inclusion in the category (the "genus", so to speak) “bird"' (Coseriu 2000 [1990]: 39). See also (Van der Gucht, Willems \& De Cuypere 2007).

${ }^{17}$ 'La lingüística cognitiva propone una equivalencia directa entre el significado y la conceptualización'.

18 'Igual que sucede con la conceptualización, el significado no se puede entender si se considera descontextualizado'.

${ }^{19}$ See also (Rastier 1989).

| ${ }^{20}$ For instance, Geeraerts_proposes (2000:85) a 'distinction between two different levels of prototypicality': namely, between the semantic level, where prototypicality refers to the relation between 'a lexical item and its meaning', and the referential one, where it refers to the relationship between 'a lexical item in one of its meanings and the referent corresponding to that meaning'. He intends that his two levels allow differentiating between 'the true meaning differences' (which involve polysemy) and 'referential specifications' (which involve vagueness). He uses prototype theory to explain 'various forms of salience effects' and pleads for 'a typology of salience phenomena' within lexical semantics. (See also Geeraerts 1993, 2010.)

${ }^{21}$ For a detailed critique of CL's approach, see (Willems 2011).

${ }^{22}$ My strategy reprises, mutatis mutandis, Coseriu's (1992a) critique of prototype semantics and its variants. 
consideration in explaining linguistic meaning. CL conceives therefore the structural relations especially in their referential dimensions and not strictly in their semantic relations within the lexical fields.

Second, overemphasis on the semantic variation of a linguistic item in language use (e.g., Geeraerts 1993, 2000, 2010; Taylor 1999, 2003; Tyler \& Evans 2001, 2003; Evans 2006) leads to an improper overlap of the word's meaning with its 'conventional uses'. ${ }^{23}$ This way of doing things shows that cognitive linguists understand semantic variation as 'a prerequisite of the flexibility with which they [linguistic items] are instantiated in language use, rather than a consequence of it' (Van der Gucht et al. 2007: 737; emphasis original).

Third, if there is an equivalence between aspects of categorization and concepts - as CL supposes - and if concepts are exclusively discriminated by their referential relations, the logical consequence is that the concepts are meant to correspond to, or to constitute the linguistic meanings themselves (signifiés) (see e.g. Taylor 1999, Langacker 1987). ${ }^{24}$ In this way, not only features pertaining to prelinguistic categorization but everything that belongs to contextual use and interpretation may become semantically relevant. Violi (2000) questions this position and rightly points out that Geeraerts and other cognitive linguists confuse categorization processes with semantic ones. They reveal a tendency to introduce psychological phenomena, ${ }^{25}$ 'which may well have no semantic relevance at all', into semantics. ${ }^{26}$ Violi's argument is generally agreeable, with some amendments, to Coseriu's more fundamental objection. Indeed, it is fair to say that Coseriu's critique applies not only to Lakoff's semantics but to all cognitive linguistics that takes into consideration only the contextual meaning and for which linguistic knowledge reduces to 'the knowledge related to the things'.

In spite of his critique of prototype semantics and the Lakoff approach, Coseriu does not intend that extra-linguistic knowledge should be excluded from semantics. His concern is only that these trends mistake linguistic meanings (Bedeutungen) for the things designated and for the knowledge related to them. He has pleaded for many years for a skeological linguistics (from Gr. skeuos 'thing') but he understands it not as Sachsemantik ('semantics of things') but as sachbezogene Semantik: i.e., a

\footnotetext{
${ }^{23}$ Analizying Tyler and Evans' $(2001,2003)$ concept of polysemy, Van der Gucht writes that cognitive linguists' reasoning 'is circular and demonstrates nothing: first the meaning of the linguistic item is explicitly identified with its readily apparent "polyvalence"..., then, in a second move, this demonstrable polyvalence - i.e., the fact that one meaning (signifié) can take on various (theoretically: an infinite numbers of) senses when applied to different referents - is declared to be, by fiat, the meaning (or meanings) of the linguistic item under consideration)' (Van der Gucht et al. 2007: 739).

${ }^{24}$ For a more detailed critique, see (Willems 2011).

${ }^{25}$ See also Van der Gucht's ' (Van der Gucht et al. 2007: 739) critique of the cognitive linguists' strategy of positing different psychological motivations to pick out different senses of a word.

${ }^{26}$ Violi pleads for the replacement within lexical semantics of categorial prototypicality with semantic typicality. Taking a 'usage-based' perspective, she assumes that meanings are 'never completely context-free, but are instead always indexed to some standard context of reference' (2000: 113). Violi defines 'the semantic typicality' as 'the habitual or regularity aspect of meaning' (Violi 2000: 112). Although I do not take a position on this, I believe that her most insightful contribution to semantics is in emphasizing and describing the regularity and structure of the 'standard context of reference' against which is supposed to appear the semantic typicality. Her ideas can be better valued in Coseriu's theory of the contexts of speaking (see Section 3.1.)
} 
kind of semantics that is built upon - so dependent on - the semantics of linguistic meaning and not separate from it. Kabatek raises the same objection against CL: 'if one accepts that we structure the world pre-linguistically, is then this structuring the immediate foundation of linguistic structuring?' (Kabatek 2000: 201; my translation ${ }^{27}$ ). His position is that 'we do not move from things towards language or from the designata towards the linguistic meaning, but rather we find linguistic signs, which, as signs of a [linguistic] community, "are already there", related to things' (Kabatek 2000: 201; my translation ${ }^{28}$ ) - as 'historical ways of speaking'.

\section{FROM COGNITIVE FOUNDATIONS TO INTEGRAL SEMANTICS}

\subsection{The functional autonomy of language}

Coseriu's (2000 [1990], 1999) critique of the first conceptual level of CS theory and Kabatek's wellmade point raise one of the most challenging problems to be solved at present. A common idea among researchers in $\mathrm{CL}^{29}$ is that language (as well as any other form of cognition in general) is grounded in our embodiment. They suppose a continuum between body, mind and language, with a straightforward continuous movement from perception to language - the only variation consisting in the degrees of abstractness involved in the process.

Consider the problem in the usual terms of embodiment: is linguistic meaning 'disembodied' or not? Except for those from the first generation of cognitive science, most cognitive researchers would agree that linguistic meaning is embodied. As far as I know, there is only one study examining the problem of disembodied meaning head on: (Zlatev 2009b). Zlatev considers the possibility of disembodied meaning when he characterizes the relation between meaning and embodiment at the level he calls the extended body: 'with the ascent of language, and especially external representations such as notions, pictures and diagrams, the role of the human body here is relatively marginal. Thus, in one sense, one can argue that meaning at this level becomes "dis-embodied". But we could also describe this as a matter of "extended embodiment"... We could use the term "extended body" to stand for all those modes of meaning and communication that both transcend the limits of human embodiment' (Zlatev 2009b: 155). ${ }^{30} \mathrm{I}$ choose the opposite approach and argue for the disembodied character of linguistic meaning.

\footnotetext{
27 'Die Frage aber ist, ob wir die uns bekannte Welt vorsprachlich strukturieren und, wenn ja, ob diese Strukturierung die unmittelbare Grundlage sprachlicher Struktur ist'.

${ }^{28}$ 'Wir kommen nicht von der Sachen zur Sprache oder vom Designat zum Semnificat, sondern finden der sprachlichen Zeichen, die als Zeichen der Gemeinschaft sozusagen "schon da sind", im Bezug auf die Sachen'.

${ }^{29}$ See e.g. (Lakoff 1987; Johnson 1987; Langacker 1987; Gibbs 2003; Taylor 1999, 2003; Geeraerts 1993, 1997, 2000, 2010; Tyler \& Evans 2001, 2003).

${ }^{30}$ His position should be understood mainly as a rejection of the disembodied and abstract models of cognition from the first generation of cognitive science. Zlatev's notion of extended body suggests his affiliation to that perspective in cognitive science that emphasizes the prominent role in cognition of the body (e.g., Gallagher 2005, Thompson 2007, Zahavi \& Gallagher 2008) and embodiment - sometimes conceived in a radical manner: see e.g. (Clark 1999).
} 
The proponents of embodiment theory, Lakoff and Johnson, answer the question positively. So Lakoff (1987: 286) explains that the concept of WAITER is understood relative to a restaurant scenario. Any linguistic expression gets its meaning either by 'being associated directly' with 'idealized cognitive models' or by 'having elements of the idealized cognitive models' (Lakoff 1987: 291). Because the WAITER concept is structured internally by different image-schematic structures illustrating the restaurant scenario, it is supposed that experiential content is part of linguistic meaning. The CS view can be neatly summarized: if language only reflects cognitive thought processes and prelinguistic cognitive structures, then linguistic meaning is embodied. Lakoff's position could be characterized as a very strong version of embodiment. It reduces language to conceptual structures and ignores any contribution of language to human cognition.

Is there any proper content of linguistic meaning? Does the linguistic meaning of 'waiter' not have a proper content separate from the contextualized, extra-linguistic restaurant scenario? Unlike Lakoff, many scholars from CL acknowledge the presence of an independent level of linguistic - or semantic - representation (see Section 1.3). At first glance, such a position is deceptive and could lead one to presume that the CL school adopts a much more moderate view than Lakoff defends. The evidence shows the opposite. Willems (2011) demonstrates in extenso that CL's notion of linguistic $\operatorname{sign}^{31}$ is based on the same underlying premise of continuity from sense perception to language as in Lakoff's account and sees in this the cognitive linguists' main error. He concludes that their notion of 'semantic representation' is completely fallible, since it involves aspects that pertain to 'general encyclopaedic knowledge' (involving 'conceptualisation', 'imagery', or 'construals', and different 'pragmatic aspects') and not to 'language-specific semantic knowledge'. He points out that cognitive linguists customarily see the linguistic sign 'in terms of the place where world knowledge is associated ("paired") with a "linguistic form"' (Willems 2011: 38). This highlights a misunderstanding of the nature of the linguistic sign - a fallacy that seems to be pervasive in CL. Most significantly, all these facts undermine any attempt by CL to account for the historical and intersubjective dimensions of language, so long as a proper notion of linguistic meaning ('semantic representation'or 'concept'/signifié) is still missing.

Though the product of a different tradition of research, Willems' critique is partly compatible with that initiated by researchers of 'the minor stream' in CL: e.g. (Itkonen 2003, 2008; Zlatev 2007, 2008a, 2010; Sinha 1999; Sinha \& Rodríguez 2008; Harder 2007). These scholars systematically demonstrate that embodiment theory is insufficient for linguistic explanation and, especially, for any embodied theory of language. With the emergence of the third generation of cognitive science, it becomes clear that, despite the undeniable efforts of many earlier researchers to link language to embodiment, the necessary conceptual apparatus to provide a coherent account of language and

\footnotetext{
${ }^{31}$ Willems analyses the conception of Taylor (1999), and explains that Taylor's view is shared by a considerable number of cognitive linguists.
} 
cognition has been lacking. The source of the failure resides in the foundational concepts of CL such as image schema and embodiment.

In numerous articles, Itkonen and Zlatev argue convincingly for a damaging denial of the role of consciousness in $\mathrm{CL}$ - a denial that originates in the role given to the concept of "cognitive unconscious' in mainstream cognitive science (Lakoff \& Johnson 1999). This notion remains in the headlines of many accounts of embodied cognition (e.g., Gallese \& Lakoff 2005) despite all clear evidences to the contrary. ${ }^{32}$ Itkonen and Zlatev argue that, even when the role of consciousness is acknowledged, it is misinterpreted: e.g., Itkonen (2008) shows that Talmy (2000) wrongly relates consciousness to introspection and identifies linguistic meaning with subjective, 'private', psychological structures accessible to consciousness through introspection. This raises two major problems. It shows little sensitivity toward the social or intersubjective character of language and particularly toward the understanding of linguistic knowledge as 'common', intersubjectively shared knowledge. Even when the public character of linguistic meaning is conceded, it is reduced to 'the production of sounds or written symbols' (Chafe 1994: 12, cited in Itkonen 2008: 17). Itkonen (2006) demonstrates how this much repeated fallacy is based on a misunderstanding of what is logically primary, 'objective' knowledge - i.e., social norms and conventions - versus what is secondary, subjective, 'individual' knowledge - even though the social norms are accessible only by means of this fallible subjective knowledge. The fallacy is widespread in $\mathrm{CL}^{33}$, both in experientialist accounts (Lakoff 1987, Johnson 1987, Langacker 1991) and in embodiment theory (Lakoff \& Johnson 1999) and stands as evidence for the lack of an adequate concept of intersubjectivity. ${ }^{34}$ Third generation scholars (Itkonen 2008, 2009; Zlatev 2008a, 2010, 2011; Sonesson 2009) are consistent in stressing that the reduction of common knowledge to individual, 'private' experiences - which are to be studied through observation and introspection - leads to a self-destructive tendency to naturalize the 'human' sciences. ${ }^{35}$ They argue that the 'public vs. private' dichotomy could not properly be solved by the conceptual tools of the earlier generation, because those tools were not compatible with a phenomenological perspective (Zlatev 2010, Sonesson 2009, Harder 2007). Applied to human sciences, the phenomenological perspective ${ }^{36}$ should necessary start out from those facts having the

\footnotetext{
32 Itkonen $(2008,2009)$ and Zlatev $(2007,2008$ a) provide at least three 'conceptual' arguments to demonstrate 'the dependence of language on consciousness'. First, linguistic meanings are commonly shared contents within a linguistic community, and this implies consciousness. Second, as common knowledge they are accessed by 'normative intuitions' and thus involve the conscious knowledge of 'rules of correctness'. Third, judgements of correctness necessary imply a conscious subject.

${ }_{33}$ Another good example is the case of mental imagery, which is supposed to be conventionalized or shared. Itkonen (2006) argues that 'conventional mental image' is a self-contradictory notion, because 'conventionalized' means socially shared. Thus, it is opposed to everything individual and psychologically subjective (see also Zlatev 2010, Sinha 1999, Harder 2007).

${ }^{34}$ The essays on intersubjectivity in The Shared Mind: Perspectives on Intersubjectivity (Zlatev et al. 2008) demonstrate the constant efforts to link intersubjectivity to other central concepts in cognitive science, such as embodiment (e.g., Gallagher 2005; Zahavi 2003; Sonesson 2007, 2009) and language (Itkonen 2003, 2006, 2008, 2009; Zlatev 2007, 2008a, 2010; Sinha 1999; Sinha \& Rodríguez 2008).

${ }^{35}$ For a defence of these sciences as hermeneutical sciences in CL, see (Itkonen 2003, 2008; Zlatev 2010, 2011).

36 ...Or rather, 'phenomenological method': see (Sonesson 2009).
} 
character of evidence in consciousness when one reflects on them. ${ }^{37}$ With few exceptions, CL fails to adopt a phenomenological perspective. Zlatev (2010: 436-438) writes that, although some aspects of CL could be compatible with a phenomenological perspective, one fundamental factor gets overlooked: the problem of linguistic representation and, thus, the linguistic sign. The way these notions have customarily been treated in CL makes them the most challenging ones for an embodied theory of language.

From the phenomenological and hermeneutical perspective of third-generation cognitive science, Zlatev $^{38}$ claims $(2007,2008$ a, 2010) that any comprehensive theory of language should start from the essential properties of language: conventionality, representationality, and conscious accessibility. ${ }^{39}$ The conventionality of language refers to the way linguistic meaning is shared by all members of a community who speak a given language. Language is a social institution that exists 'primarily between people rather than (only) within people' (Zlatev 2007: 243; emphasis original). If language presupposes lexical meanings that are shared by a community of speakers, and if the community know how to use the rules for combining these meanings, it means that language is accessible to consciousness (Zlatev 2007; see also Zlatev 2008a, 2011). As for representationality, Zlatev argues (2007) that what CL most needs to explain the embodiment of language is a concept of (linguistic) representation. ${ }^{40} \mathrm{He}$ offers his own concept of representation as a relationship between expression and meaning (or content) on the one hand, and between an assertive speech act and reality on the other. He claims that the relationship between expression and meaning is similar to Saussure's account of 'signifier' and 'signified', with the qualification that the meaning is considered 'as conventional context-general content' (Zlatev 2007: 248). This concept is, he believes, the only concept on the strength of which the embodiment of language can be explained. It is able to link language to the sensorimotor roots of cognition (Zlatev 2005) and, simultaneously, account for the qualitatively new and ontologically 'higher' level of language (Ikegami \& Zlatev 2007). From the viewpoint of cognitive semiotics, the concept of (mental) representation is similar to that of a sign, described by three major features. (1) A representation occurs within an act of imagination, rather than perception. ${ }^{41}$ (2) The act of imagining implies a conscious subject who is supposed to imagine a specific action or event. (3) The conscious subject should be able to differentiate between an expression and its content,

\footnotetext{
${ }^{37}$ Applied to linguistics, the phenomenological method aims to provide 'a careful analysis of what appears in consciousness when we reflect on our knowledge and use of language' (Zlatev 2010: 422).

${ }^{38}$ In the remainder of this section, I will refer most to Zlatev's approach. He is one of the most outspoken proponents of the new perspective, and he provides the most integrative attempt developed within the thirdgeneration framework. He grounds his research in, and corroborates it with, the previous works of representative scholars in cognitive science (e.g., Itkonen 2003, 2008, 2009; Sonesson 2006, 2007, 2009; Zahavi 2001, 2003; Gallagher 2005; Gallagher \& Brøsted-Sørensen 2006; Gallagher \& Zahavi 2008).

${ }^{39}$ Zlatev grounds his theory in linguistics in Itkonen's 'realistic' stance (Borcilă forthcoming).

${ }^{40}$ Zlatev $(2007,2009$ a) notes the difficulties one may encounter in rehabilitating the concept of (mental) representation. The second generation entirely rejected this concept, because its use in the first generation of cognitive science led to versions of mentalism and disembodied cognition.

${ }^{41}$ As an act of imagination, its primary function is to re-present non-present actions or events, rather than to reiterate the perception. Zlatev makes use of Piaget's (1945) notion from developmental psychology of 'symbolic function', by which Piaget explains the emergence of symbols in early childhood.
} 
so that they neither overlap 'in time or space', nor are they 'perceived' to be 'of different nature' (Sonesson 2007: 93, emphasis original; see also Zlatev 2009a).

I am in agreement with Zlatev, at least on the following points. First, the emphasis on linguistic activity as the activity of a conscious subject and, thus, the redemption of human subjectivity within the field of human sciences represents a significant advance in CL over previous generations as well as a longstanding tradition in linguistics research that most likely originates in Nineteenth Century positivism. Second, the systematic consideration of the intersubjective nature of linguistic meaning in terms of shared or common knowledge is a breakthrough from the second-generation theoretical framework, laying the foundations for a new science of linguistics. Third, the acknowledgement of the cognitive character of linguistic meaning and, thus, the functional autonomy of language provides a common ground between CL and other traditions of linguistic research such as IS. In spite of all these, certain aspects of the approach remain in need of clarification.

Although this third-generation research recognizes the functional autonomy of language and makes a clear distinction between pre-representational cognition and language, it also assumes that language is partially embodied. It is not my intention to deny this or its relevance. As said, this 'minor stream' within CL acknowledges language as 'the main "cognitive revolution" in ontogenesis' involving 'one higher ontological level: that of consensual social reality, mutual knowledge' (Ikegami \& Zlatev 2007: 248). Basically, this agrees with my position.

Yet, if one assumes that language is "the main "cognitive revolution" in ontogenesis' and that it introduces a 'higher', 'ontologically different' level to the pre-representational one, it still remains to be explained how the transition from pre-reflectively shared mimetic schemas ${ }^{42}$ to the conventionality of language occurs. More specifically, it is unclear what the content is that distinguishes the level of protolanguage $^{43}$ from the immediately superior level. Although the symbolic nature of language is acknowledged through its 'systematic' and 'conventional/normative' character ${ }^{44}$, it is disregarded in the very moment that linguistic 'symbols' or semantic conventions are acquired in ontogeny.

The dilemma could be solved through a deeper exploration of the representational character of language. In my view, the crucial factor that motivates the transition from pre-verbal mimetic schemas to language is the breakthrough from the representational toward the symbolic dimension of the sign. The transition to the ontologically 'higher' level of language coincides with the acquisition of symbolic representation, where the primary mental representations are replaced by the symbolic ones. The emergence of this new, symbolic level presupposes the rearrangement of the world according to

\footnotetext{
${ }^{42}$ Zlatev defines mimetic schemas as 'dynamic, concrete and pre-verbal representations, involving the body image, which are accessible to consciousness, and pre-reflectively shared in a community' (Zlatev 2005: 334; emphasis original). He specifies that, although language is grounded in these mimetic schemas, they 'do not constitute linguistic meanings', because, in opposition to language, mimetic schemas lack the conventionality and systematicity of language.

${ }^{43}$ See (Zlatev 2008b, 2009a) for details of the mimesis 'hierarchy'.

${ }^{44}$ The public and normative character of language presupposes release from individual representation with its subjectivity.
} 
the clear-cut symbolic patterns of language. ${ }^{45}$ Within this new world structuring, the role of pre-verbal representations, if any, becomes marginal. The conventionality of language is not something that could just be added to one's pre-verbal representations; rather, the representations are reinterpreted from the viewpoint of the emerging language categories. I am not sure if Zlatev would agree, but I believe that this is the genuine sense in which one can speak of a 'qualitatively new' and ontologically 'higher' level of language. In any case, from the IS perspective, the forms of pre-representational cognition are no longer part of linguistic meaning proper ${ }^{46}$; instead, they become active in contextualizing the speech acts by means of which one refers to the world.

\subsection{On the cognitive nature of linguistic meaning}

Beyond the above-mentioned problem, I agree with Zlatev $(2007,2010)$ that language has the properties of representationality, conventionality, and accessibility to consciousness. In Coseriu's linguistic theory, these properties are re-interpreted in a dynamic/energetic perspective. Analogously to Zlatev, Coseriu speaks of three essential - indeed, primary - universals of language: creativity, semanticity, and alterity (see Coseriu 1987 [1978], 2001) ${ }^{47}$. They are sine qua non to language.

Zlatev's representationality property corresponds to Coseriu's semanticity of language, both of which refer to language's cognitive dimension. The most basic function of language is to signify the world: that is, to transform the pre-verbalized world into a 'semantic' one, a world one can represent in the mind, think upon, and understand. This basic function coincides with language's finality: to create semantic (or symbolic) entities in order to structure one's experience in the world. I wish to emphasize Coseriu's thesis of the 'absolute priority of language' (see e.g. Coseriu 2001), because this Humboldtian thesis distinguishes IS among other contemporary linguistic theories. CL assumes that the world is structured either pre-conceptually or conceptually and that pre-linguistic cognitive structures ground linguistic meaning. Certainly, Coseriu ${ }^{48}$ does not deny that the world may be structured prior to language. However, in his view, the claim that pre-linguistic structures are the bedrock of language is an avoidance of language's cognitive character and, as such, a denial of language's functional autonomy. ${ }^{49}$ Coseriu (1992b: 22) argues that, although the world may indeed be structured prior to language, this pre-verbal structuring (Artikuliertheit der Welt) cannot be known independently of language: for anything to be known, it must transcend the individual mind and be

\footnotetext{
${ }^{45}$ See also (Coseriu 1992b).

${ }^{46}$ Meaning proper is the content of the historical level in Coseriu's matrix and methodologically corresponds to Saussure's signifié. For further distinctions and its delimitation from designation and sense see (below, 2.3, and De Cuypere 2008; also Van der Gucht et al. 2007, and Willems 2011).

47 The language's 'accessibility to consciousness' is implicitly assumed in IS as the underlying property of language.

${ }^{48}$ See (Coseriu 1992b), Coseriu's most important study in this respect.

${ }^{49}$ See also the critique of Van der Gucht and colleagues (2007), which demonstrate that this practice became a commonplace today in cognitive sciences. The authors suggest that it is a consequence of the 'embodiment postulate', which derives from a 'deeper epistemological premise', namely that 'language mirrors underlying conceptual structures, which in turn are determined by the typically human experiences of human beings vis-àvis extralinguistic reality' (Van der Gucht et al. 2007: 750; emphasis added).
} 
objectified as known through the knowledge of another. (See the discussion about the alterity of language below.) Coseriu (e.g., 1988: 206) sometimes describes this linguistic knowledge of the world in Leibniz's (1684) terms: 'cognitio clara distincta inadequata'. Coseriu holds that Leibniz's 'scientifically inappropriate knowledge' is a form of knowledge through intuition, sufficient for the linguistic knowledge to be perceivable as objective knowledge. Concerning the representational character of language, he emphasizes the symbolic and the intuitive $e^{50}$ nature of linguistic categories. In his view, the naïve speaker does not use abstract categories in speaking, but rather depends on linguistic intuitions. Viewed as activity (enérgeia ${ }^{51}$ ), this linguistic intuition is meant to create a unitary 'image' of both the object and its infinite possibilities (Coseriu 1972; see also Borcilă 2003, forthcoming). Coseriu sometimes refers to such intuition as Husserl's eidetic intuition ${ }^{52}$ (see e.g. Coseriu 1967 [1954]), with the difference that Husserl's eidetic intuition is captured within historical ways of speaking: i.e., within language. Thus, while as intuition language works as an image of the world, as eidetic intuition it is apprehension of the unity of thing and of its infinite possibility.

Zlatev's (2007, 2008a, 2009a) property of conventionality, immanent to the social character of language, roughly corresponds to Coseriu's second universal: the alterity of language. For Coseriu, this property is conceived from a dynamic perspective and, thus, signifies not only already shared linguistic meaning (which corresponds to the historically given' viewpoint), but also, and foremost, the creation of common historical meanings. In other words, before people can share linguistic meanings, they need to create them. This creation is a common achievement in objectifying linguistic meanings for both ego and alter ego. Coseriu summarizes the importance of the viewpoint of activity (enérgeia) in language (1977/2001: 25): 'it can be said that language as enérgeia is, in the same act, both knowledge and... objectivation of this knowledge'. ${ }^{53}$

The third language universal, creativity, has a prominent role in Coseriu's thinking; indeed, it should be conceived as logically primary, because it represents the primum movens of the whole linguistic activity. ${ }^{54}$ IS understands the finality of language as immanent in semantic creativity, evoking the intention to create shared meanings in order to signify - or refer to - the world. Borcilă (2003: 58) clarifies the consequences for linguistic science of this basic assumption about language's creative dimension: any determinist/causal explanation of the human cultural activities is ruled out,

\footnotetext{
${ }^{50}$ Coseriu appropriates the concept of intuition from Croce, who distinguishes between intuition and concept (Coseriu 1972, 2003; see also 1988).

${ }^{51}$ Coseriu has employed the concept of enérgeia since 1952 (Coseriu 1985 [1952]; see also 1988 [1979], 1985, 1988, which discuss the internal dynamics of and functional relationship between enérgeia, dynamis, and ergon). For further readings on the importance of these concepts in epistemology of integral linguistics see (Di Cesare 1988; Laplace 1994; Borcilă 2002, 2003).

52 See also (Vîlcu 2010). As far as I know, this is the first book to explore systematically the phenomenological grounds of Coseriu's thinking.

53 'On peut dire que le langage en tant qu'enérgeia est, dans une seul et même acte, connaissance et en même temps fixation et objectivation du connu'.

${ }^{54}$ For Coseriu (1952/1985, 2001), creativity plays an essential role in the entire range of human cultural activities, not only in linguistic activity. Among these activities, language is the foremost and the basis for all the others.
} 
and the study of human cultural activities is accounted for from the perspective of their inherent finality and intentionality, not aside from them (see also Section 3.3).

Coseriu's three essential universals of language - which, together, constitute the signifying function of language - lead to a particular way of understanding the cognitive nature of linguistic meaning. The cognitive character of language is described by its double dimension: on the one hand, language mediates between ego - knowing subject - and world; on the other, language mediates between ego and alter ego - other subjects. This double dimension - something that is known is also recognized to be known - raises linguistic cognition to the level of cognoscitive activity ${ }^{55}$, and so distinguishes it from pre-representational cognition.

\subsection{Three levels of linguistic content}

Coseriu's distinction of three levels of linguistic content in his matrix ${ }^{56}$ is highly operational. (Linguistic) meaning proper is ranged on the historical level, as 'the linguistically-given content in a particular language, the particular form of the possibilities of designation in a given language' (Coseriu 1985: xxx). Designation is ranged on the universal level, as the relationship of linguistic meaning to 'extralinguistic reality itself, be it a state of affairs or the corresponding contents of thought' (Coseriu 1985: xxx). Sense is defined as the text's content proper: 'the particular linguistic content which is expressed by means of designation and meaning, and which goes beyond designation and meaning in a particular discourse, such as a speaker's attitude, intention or assumption' (Coseriu 1985: xxx).

This basic semantic distinction is not only useful but requisite today, when so many perspectives on linguistic meaning are confused by the lack of it even as each claims to exhaust the phenomenon of (linguistic) meaning or provide the best explanation for it. Coseriu's matrix shows that these seemingly conflicting perspectives on linguistic meaning propose, in fact, complementary explanations and can be ranged on different levels in his matrix, according to which aspects they choose mostly to emphasize.

As I have shown in Section 1.3, mainstream CL mistakes (linguistic) meaning for designation. To make the distinction between meaning proper and designation more palpable, consider the following example: I am walking with my friend, and I am eating with the spoon. Coseriu (1988) argues that the relationship between designation and meaning proper is asymmetrical. The meaning of with is the same in both statements, but the designation thereof is different. The distinction is established already in the definition of meaning proper, as 'the particular form of the possibilities of designation in a given language'. Meaning proper is pure virtuality (see Section 2.2), with neither concrete nor Platonic existence outside the act of designation (Kabatek 2000). Unlike Saussure's signifié, Coseriu's meaning

\footnotetext{
${ }^{55}$ The term was first used by Martinez del Castillo (2003) in relation to Coseriu's IS, for the same reason I use it here: to express the double dimension of language's cognitive nature.

${ }^{56}$ The matrix is described extensively in (Coseriu 1985, 1988; see also Zlatev 2011).
} 
proper has a unitary, 'positive' content - einheitliche Bedeutung - not just differential meaning or value. Laplace (1994: 129) correctly notes that the concept of einheitliche Bedeutung allows Coseriu to distinguish linguistic meaning within a historical language (Sprachbedeutung or einheitliche Bedeutung) from contextual meaning (Redebedeutung). Linguistic meaning within a historical language signifies the same thing in all contexts of speaking: with will always have the meaning 'und $\mathrm{X}$ ist dabei ${ }^{57}$. In contrast, contextual meaning signifies according to the linguistic or extra-linguistic context in which it appears: e.g., the instrument, the person who accompanies, etc. Such a distinction allows discriminating what is linguistic proper from that which pertains to specific contexts of speaking.

The distinction between meaning proper and its contextual variants is necessary from another perspective. As I have shown (Section 1.3), contemporary linguistics has a clear tendency to confuse meaning proper with its contextual variants and to consider the additional, contextual features of a word as linguistic meaning proper. Coseriu considers this unjustified: the contextual variants present per definitionem more features than meaning proper; for this reason, they simply cannot be confused (Coseriu 2000 [1990], 1992a). ${ }^{58}$ He pinpoints the confusion as one of the major problems in analytical semantics and argues that CL maintains the same lack of distinction. As regards the famous example '(to) climb', this distinction helps to solve, very easily, the controversial problem posed by Fillmore's example. Coseriu shows that the linguistic meaning of 'climb' implies neither downward nor upward movement, but solely movement 'on a vertical or inclined plane' (Coseriu 2000 [1990]: 28). Likewise, 'clambering' does not imply 'by means of hands and feet or paws', etc., but only 'by means of extremities'. In this way, '(to) climb' allows the same linguistic meaning to apply to very different kinds of beings - plants, people, animals - and be used metaphorically as well (Coseriu 1990: 256; see also Taylor 1999 for a defense of the cognitive stance).

\section{METAPHORICAL MEANING AND ELOCUTIONAL KNOWLEDGE}

\subsection{The knowledge of things}

It is not my intention to present all the levels of language and all the contents of Coseriu's matrix. The level where CL and IS cross their paths and are able to explain metaphorical meaning is the universal one; therefore, I will consider this level alone.

\footnotetext{
${ }^{57}$ See (Coseriu 1988: 84).

58 "For structural semantics, the "meaning" that is realised in a particular use, in an act of designation, is never the signification as such - the intralinguistic semantic entity - but always a particular variant of that entity (just like the actually realised speech sound is not the phoneme itself, but a variant). And a variant offers, by definition, more features than the corresponding functional entity. Moreover, structural semantics aims at delimiting the functional entity on the level of the language system, i.e., on the only level where the functional entities constitute a structure of idiomatic units, proper to a particular language. On the other hand, structural semantics also account for the fact that language is not only a "system", but also encompasses a level of normal language use. On the latter level, a particular variants turns out to be, in certain contexts, the "normal" variants, so that it constitutes an "invariant" of normal language use' (Coseriu 2000 [1990]: 28).
} 
As Laplace rightfully notes, the universal level is "prior (not historically, but conceptually) to the emergence of different historical languages' (Laplace 1994: 109; my translation ${ }^{59}$ ). The facts one speaks of on this level are not yet the syntactic and grammatical norms of historical language. Rather, they pertain to the semantic-referential level of language. The universal level constitutes 'a stage where the difference between language and historical language is still not required' (Laplace 1994: 108, my translation ${ }^{60}$ ). The study of competence or know-how on this level comprises, on the one hand, what Coseriu terms the grammar of enunciation: that is, the study of 'the specific functions of

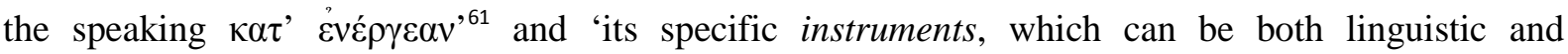
extralinguistic' (Coseriu 1967 [1956]: 290; my translation ${ }^{62}$ ). On the other, it comprises a general theory of elocutional knowledge (Coseriu 1988): that is, the study of aspects of linguistic knowledge of the world that do not belong to a particular historical language. Coseriu distinguishes between (1) knowledge of things, as the permanent frame of reference for speech acts; (2) knowledge of principles of thought used by speakers to discriminate or judge intuitively the 'congruence' (or 'appropriateness') of someone's speaking; and (3) the capacity for interpreting particular language functions.

In what follows, I refer only to Coseriu's concept of knowledge of things, to argue for the possibility of integrating developments from cognitive science at this level: in particular, Johnson's (1987) notion of background and Sonesson's hierarchical model of things within the lifeworld (2001).

What does this knowledge of the world mean for Coseriu? Coseriu defines it as the implicit background of speaking: 'our ordinary experience in the world' is 'the [presupposed] background of our speaking' (Coseriu 1988: 101). Coseriu draws upon a considerable number of 'disputed' facts to circumscribe his concept. For example ${ }^{63}$, to understand such a simple statement as I plan to go to the mountains next week, one must make use of one's knowledge of how things actually are in the world. One takes for granted that there is a next week, that the sun will rise tomorrow, that another day follows after tomorrow, and that the mountains will continue to exist. What is presupposed by one's speech acts is the fact that the things are the same as one has experienced them before. These assumptions provide a background, a horizon for one's expectations about the way the world is and about the stable, normal way of things being in the world (Coseriu 1988: 102). Take another example: he boiled the piano. This sentence violates one's usual representations of things as well as the way one normally behaves: one does not normally boil pianos. A piano is for playing, not for other purposes such as eating or burning. The naïve speaker judges the sentence as incongruent to one's knowledge of the world. Knowledge of things presupposes that one has, from previous, non-verbalized experience, an intuitive understanding of how the things are in the world, what kind of behaviour is appropriate to

\footnotetext{
59 'Antérieur (non pas historiquement mais conceptuellement) a l'émergence des différentes langues'.

60 'À un stade où la différence entre langage et langue ne s'impose pas encore'.

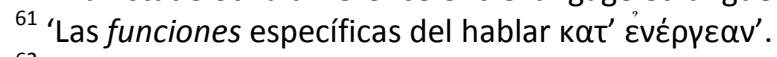

62 'Sus posibles instrumentos, que tanto pueden ser verbales como extraverbales'.

${ }^{63}$ These examples are adapted from (Coseriu 1988).
} 
each kind of things, and which are their essential properties. Coseriu's concept of knowledge of the world is clearly symmetrical to Lakoff and Turner's (1989) hierarchical model of the Great Chain of Being (which constitutes the 'basic metaphor' underlying ordinary language). The difference is that Lakoff and Turner's model comprises an ascending scale of kinds of beings, defined by their essential properties and behaviour, presupposing a more articulated but also more constraining notion than what Coseriu means by knowledge of the world (Coseriu 1988: 99; see also Borcilă 2003).

Using examples, Coseriu argues that people know how things are because, as human beings, they are 'beings in the world'. This world is not the world of natural sciences but the lifeworld: a world of lived experiences shared with other human beings. For Coseriu, knowledge of the world is far from disembodied - making clear to which kind of reality his definition of designation refers. It is not the objective world presupposed by objectivist referential theories; his linguistic conception of it is not an attempt to plug into the objectively real world. Rather, it is constituted by one's lived and felt experiences as a being in the world: to put it simply, it is Husserl's 'lifeworld'. As Sonesson (2001) argues, this lifeworld is far from being the world of natural sciences. He demonstrates that this is the world of common sense, the world to which one has the most direct access. 'The common sense world could be populated with strange phenomena such as "two-dimensional objects" (Sonesson 2001: 30). In similar manner, Coseriu argues that even the most familiar sentence such as the sun sets down is based on one's naïve experience of the world. Obviously, the naïve speaker's knowledge should not be confused with that of the scientist. Nobody would reject the naïve speaker's expression, countering that it is not the sun that revolves around the Earth, but the opposite (Coseriu 1988).

For Coseriu (1988: 96), every historical language has restrictions concerning knowledge of the world, even as those restrictions do not pertain to rules of an historical language but to general knowledge of the world. Consider the example: look! A woman with legs! Coseriu (1988: 102) writes that this statement is not incorrect as regards our knowledge of English; indeed, such constructions are possible in any language. Rather, the statement is incongruent with one's knowledge of things: every speaker judges such sentences intuitively as incongruent with implicit reference to what one takes for granted in one's knowledge of the world. Naïve speakers normally do not emphasize what they previously have taken for granted. We know that a woman usually has legs; it is not necessary to specify so when speaking. A statement like the one above would be the normal way of speaking in a world where women have no legs. In such a world, a woman with legs would be an exception; the specification 'with legs' would signal the existence of a new, different kind of woman. In other words, what is part of one's knowledge of the world should, usually, remain non-thematic. In the example, the non-thematic element has been emphasized and become thematic. As a result, an incongruence took place. Sonesson (2001) writes of the lifeworld (2001: 85): 'I discovered that it was necessary to suppose this world to be furnished in a particular way, notably containing hierarchies ascribing relative "values" to things'. He goes on (2001: 94) to describe the lifeworld as the 'presupposed background of all ordinary sign processes' and examines how both thematic and non-thematic 
background elements are activated within those sign processes. One should ask whether thematic and non-thematic background elements function in the same way in sign processes and language. Sonnesson's development of Husserl's concept of lifeworld within his ecological semiotics ${ }^{64}$ could provide a noteworthy contribution to metaphor theory on the universal level of language, at least in respect to the basic model of lifeworld hierarchy: 'lower things', 'higher things', and 'ultra-things'.

Coseriu's knowledge of the world is not essentially incompatible with Johnson's (1987) notion of background, if one disregards that notion's individualistic bias; see Section 1.2. Johnson defines background as interwoven networks, laden with image-schematic structure. His notion relies on a more basic notion of image schema as an intuitive, unconscious, and non-propositional 'recurrent pattern, shape, or regularity' in and of our experience in the world. The feature that makes the image schemas play a crucial role in the background network is that they 'are never context-free - they depend upon a large background of shared schemata, capacities, practices, and knowledge' (Johnson 1987: 30).

The concept of image schema is controversial in many respects and has been critically questioned in e.g. (Hampe 2005). In spite of all its shortcomings, the image schema's' character of constituting 'interwoven networks' is an avenue to explore. For Johnson, image-schematic networks form an ontological background in the mind: the background is not the objective world anymore but rather its projection in our minds. This may, indeed, represent a real advance in describing background knowledge in terms close to Coseriu's notion of knowledge of the world. ${ }^{65}$

\subsection{Metaphorical incongruence and the context of culture}

It is time to return to conceptual metaphor. I suggest that, by understanding conceptual metaphor as pertaining to a mental space prior to the signifying semantic space of language, CS fails to explain why metaphorical speaking exists. It is true that, using this kind of 'metaphorics of the mind' (Gibbs 1994) and the functional principle of mapping or projecting from source to target domain, one could handle descriptive data concerning basic mental operations. The idea of metaphor as projection, and the explanation of how that projection from source to target domain works are certainly substantial advances in metaphorology. Further, these findings are relevant for describing the operations of metaphorical designation - but only if they are interpreted within a semantic conception of metaphor, able to explain metaphorical creativity. What remains unexplained in the CS account is 'the intention' or 'the finality' of such meaning creation. CS fails to explain the very premise from which it starts: namely, the way metaphorical speaking is rooted in one's mode of relating to the world and understanding it. As Borcilă (2003) argues, CMT's shortcoming lies in cognitive semanticists'

\footnotetext{
${ }^{64}$ The notion of ecological semiotics originates in James Gibson's ecological, environmental physics. Within the framework of his phenomenological semiotics, Sonesson reinterprets Gibson's original insights to account for 'a science of "the natural world"', where nature 'as we experience it is not identical to the one known to physics, but is culturally constructed' (Sonesson 2001: 96).

${ }^{65}$ See also (Zlatev 2011). Zlatev redefines image schemas as 'principles of thought', pertaining to the universal level in Coseriu's matrix.
} 
subordination of the language function to the other alleged "cognitive" processes of the human mind. From an IS perspective, there is no cognitive reality of metaphor outside language: the metaphor cannot be conceived as content of thought independent from the primordial linguistic structuring of experience. Rather than pertaining to a pre-verbal realm of thought, metaphor creates verbal expression and mental content simultaneously in a new designational entity or 'perceptual aspect'. Coseriu argues that the same kind of semantic creativity is involved in both metaphor and language. The only difference is that metaphorical creativity represents the maximal form of semantic creativity. Unlike CS, the integral paradigm regains the intention to create new designative metaphorical contents within the signifying function of language itself (Borcilă 2003).

I subscribe to Borcilă's argument that, in the context of contemporary scientific research, Coseriu's IS provides the most solid foundation for developing a viable theory of metaphor. As early as 1952, Coseriu writes (1985 [1952]: 80, 97, my translation, see also Borcilă 2003): 'linguistic knowledge is often metaphorical knowledge ${ }^{, 66}$ and metaphorical knowledge is rooted from the beginning in the 'initial denomination of what is to be known' ('the cognoscible') ${ }^{67}$. Coseriu's early attempts to elaborate an integral theory of language foresaw the need for 'the scientific foundation of metaphorology as [a] core field in the linguistics of speaking' (Borcilă 2003: 55; my translation ${ }^{68}$, emphasis original; see also Willems 2003: 4). Yet, Coseriu never developed an extensive theory of metaphor. Except for the 1952 study, where one finds only the theoretical foundations for a theory of metaphor in everyday speaking, Coseriu never systematically discussed the topic of metaphor. Further developments of the integral theory of metaphor were thus necessary. In recent years, much work on this has been done within the 'integralist' studies program in Cluj-Napoca. This work accepts the idea of trans-domain projection - or mapping - of 'images', but reinterprets it as occurring between two linguistic contents. It sees the main contribution of CS in describing the mechanism of metaphorical designation. Take the example: this woman is a cow. To categorize a new aspect of experience in the speech act, two experiential domains - of 'woman' and of 'cow' - are brought together. The new aspect pertaining to the target domain - 'woman' - cannot be categorized in the source domain 'cow'. A designational incongruence occurs. Once the new aspect of experience is analogized within the image-schematic structure of the source domain 'cow', the incongruence in designation is suspended in favour of a new, reinforced congruence.

The image from the source domain is not part of the word's meaning proper but part of the background knowledge one acquires through previous experience. If one looks closer at this (shared) image, one notices that it is not a universal device. Some communities of speakers would associate the image with one's insensitivity, others with something sacred. Even as the image becomes a thematic background element, it brings forward a plethora of assumptions shared within any given cultural community. The sociocultural perspective in CS legitimately argues that experience is a matter of

\footnotetext{
66 'El conocimiento lingüístico es muchas veces un conocimiento metafórico'.

67 'Denominación inicial de lo conocible'.

68 'Intemeierea ştiintifică a metaforologiei ca domeniu central al lingvisticii vorbirii’.
} 
permanent interaction with and within a cultural world. Coseriu also proposed (Coseriu 1967 [1956]) a comprehensive theory of contexts, arguing that every speech act activates contexts in which the speech act is being produced. The contexts of speaking constitute its permanent frame of reference (see also Coseriu 1981). Knowledge of things is only one of the contexts Coseriu identifies - the one that corresponds to the extra-verbal context of speaking. His concept of context of speaking divides into (1) idiomatic, (2) verbal, and (3) extra-verbal contexts. Extra-verbal contexts further divide into (a) physic, (b) empiric, (c) natural, (d) practical, (e) historical, and (f) cultural ones. The cultural context comprises the cultural tradition of either a community of speakers or all of humanity. Coseriu includes here mythology as well as traditional scientific and literary works (Coseriu 1967 [1956], 1981). If one takes into account discoveries of researchers within the sociocultural perspective in cognitive science, one must accept that the cultural context of speaking is not just one extra-verbal context among others, but rather the underlying context for all the rest (see also Coseriu 2000a, 2000b).

\subsection{Creativity and metaphor}

Apart from the cognitive aspect of the theory, Lakoff's CMT has difficulty explaining the creative dimension of metaphor: in particular, the creation of new 'target entities'. In the afterword to the second edition of Metaphors We Live By (2003 [1980]), Lakoff and Johnson summarize the progress in the development of CMT since its first presentation in 1980. They recognize that neither the functional principle of mapping across conceptual domains nor the principle of projection explain the creative aspect involved in the creation of new designative target entities. For this reason, they offer a new explanation: a neural theory of metaphor based on the idea of 'primary experiences' - which are neurally grounded and stored in the pre-linguistic mental spaces of one's cognitive unconscious (Lakoff \& Johnson 1999). Recent developments in CMT culminate in adopting a 'naturalistic' approach to metaphor (see Zlatev 2011 for a critique).

These explanations seem to me self-defeating, because they leave no possibility for explaining the creative nature of metaphors.

CMT fails to account for the creativity of metaphor in everyday language for at least two reasons. The first concerns the embedding of conceptual metaphor within one's ordinary conceptual system under the guise of well-known conventional metaphor. If one looks carefully at the initial formulation of the theory - specifically, at the functional principle of mapping across conceptual domains - one observes that mutatis mutandis CS tacitly adheres to Saussure's claim for the primacy of the system: 'metaphors as linguistic expressions are possible precisely because there are metaphors in a person's conceptual system' (Lakoff \& Johnson 2003 [1980]: 4). It is this view of metaphor as pre-given in one's conceptual system that prevents cognitive semanticists from seeing the creative aspect of metaphor. My quarrel with CMT lies in its assumption of the conceptual system's precedence. Lakoff and Johnson's initial intention was to explain the way one conceptualizes experience through metaphor; they assumed a kind of designational process. They failed to achieve their aim because their 
research focused mainly on such aspects as the conventionality and systematicity of metaphor, not on their emergence as such.

Specifically, Lakoff and Johnson (2003 [1980]: 252) see conceptual metaphors as 'mappings in the mathematical sense' presupposing a connected situatedness of the two domains, where the source entity and the target share the relevant image-schematic structure. So the TIME IS MONEY metaphor allows inference patterns from the source domain MONEY to be used as a resource in reasoning about the target domain TIME. This says little about the projection from source to target as a process (see Zlatev 2011 for a relevant discussion). Lakoff and Johnson treat such conceptual metaphors statically by placing them in what they have called the ordinary conceptual system in line with 'the given system' model - in Coseriu's words, conceiving metaphors as ergon, not enérgeia. We can conclude that the theory is unable to capture metaphorical creativity in actus because conceptual metaphors are seen as independent, pre-existing entities in relation to the activity of speaking.

The second reason CMT fails to explain the creative dimension of metaphor is reflected in Lakoff and Johnson's 1999 formulation of metaphor as neural phenomenon - later refined (Lakoff 2008) as 'neural circuit'. Borcilă (2003: 59; my translation ${ }^{69}$ ) notices that 'cognitive semantics' attempt to... seek after an "explanation" of metaphor beyond the imaginative activities' involved in primordial linguistic cognition, along with the attempt to situate metaphor 'within a distinct pre-verbal space of "primary experiences"” attests 'a profound misunderstanding of the fundamental creative nature of language' as enérgeia. The main error of CS, made most clear by the second version of CMT (Lakoff \& Johnson 1999, Lakoff 2008), lies in reducing primary linguistic cognitive creativity to a 'conditioning factor', namely to 'primary experiences' (Borcilă 2003: 59) or, most recently, to 'neural circuits'.

Coseriu's portrayal of the signifying function of language as 'intuitive creation of signifiés' (or, simply, his understanding of language as enérgeia) and the relation between his concepts of enérgeia, dynamis, and ergon are the least assimilated and least understood dimensions of his thought within contemporary linguistic research, particularly within CL. At the same time, the principle of creativity - defined by the first concept of his crucial triad - provides the best explanatory principle for the activity of speaking as a free cognitive activity. In the particular case of CS, understanding language (and metaphor) as enérgeia helps one avoid reducing creativity to something that is not creative anymore: e.g., some biological basis or (primary) experience (Borcilă 2003).

\section{CONCLUSIONS}

The idea of mapping image-schematic structures from a source to a target domain, with the aim to express abstract concepts in terms of concrete, more clearly delineated ones, remains valuable. Coseriu

\footnotetext{
69 'Tentaţia cognitivistă de... a căuta o "explicaţie” a metaforei vorbirii în afara activităţii imaginative (în spaţiul "experienţelor primare") trădează, în ultimă instanţă, aceeaşi profundă neînţelegere a naturii fundamental creatoare a limbajului'.
} 
(1985 [1952]) argues that metaphorical knowledge is knowledge 'by images' ${ }^{70}$ In company with CS, he asserts that, with metaphor, 'we face ourselves with the human being's attempts to classify reality, not through some categories of reason, but rather through images and in the presence of some established analogies, not formally between words, but rather between "visions" that would have been aroused at a specific sequence of time in someone's creative imagination' (Coseriu 1985 [1952]): 95, my translation ${ }^{71}$ ).

Coseriu's main idea is that all language, at all levels, is creative (see Section 2.3); but the level at which creativity in actus can best be studied is the universal one. The study of this creativity in actus is the preferred theme of speaking at the universal level, because 'the creative capacity' does not belong to 'cultural, ethnic or linguistic differences'; rather, it reveals 'a certain universal unity of human imagination' (Coseriu 1985 [1952]: 80, my translation ${ }^{72}$ ). Metaphorical creation in language conceived in a deeper and broader sense than the rhetorical! - is the privileged dimension for exploring linguistic cognitive creativity.

I propose that IS could add more value to the achievements of CS by describing the mechanism of metaphorical designation: in other words, by investigating the operations of the mutual determination of universals'.

\section{Acknowledgements}

I am deeply grateful to Mircea Borcilă for his constant and enthusiast help. His suggestions substantially helped me fine tune my arguments and improve this paper. Special thanks go to Jordan Zlatev for his comments and discussions, and for giving me the support to get acquainted with the work of the third generation of cognitive science. Without the inspiring discussions with the members of the Center for Cognitive Semiotics (CCS) during my several research visits at Lund University over the past years, the present paper would have certainly looked differently. Thus, I am thankful to all of

\footnotetext{
${ }^{70}$ Coseriu's theory of metaphor has been further developed within the integralist studies program in ClujNapoca, directed by M. Borcilă. Borcilă distinguishes three semantic levels of speaking: the level of linguistic signification, the representational level, and the perceptual-skeological one. The latter is where the ideas from CS concerning image schemas and directly emergent image-schematic concepts are integrated. Imageschematic concepts structured within CS as conceptual metaphors are reinterpreted as pertaining to the representational level. Johnson's (1987) concept of image schema helps specify that the image involved at the perceptual-skeologic level is not a rich image of a particular object; rather, it has a gestalt structure that organizes perceptions of the world into coherent unified wholes of experience. Putting to one side his individualistic bias, one can say that Johnson assumes a Kantian position in stating that image schemas are supposed to exist only in the mind. They are neither psychological phenomena whose role is to organize mental representations into meaningful units nor structures within the cognitive unconscious (Lakoff \& Johnson 1999) nor neural circuits (Dodge \& Lakoff 2005, Lakoff 2008). Johnson's notion of image schema seems compatible with a phenomenological account and with the IS framework.

${ }^{71}$ 'Nos encontramos frente a intentos de clasificar la realidad, ya no mediante categorías de la razón sino mediante imágenes, y frente a analogías establecidas, no desde un punto de visto estrictamente formal, entre vocablos, sino poéticamente, entre "visiones", que deben haber surgido, en cierto momento particular, de la fantasía creadora de alguien'.

72 'El conocimiento lingüístico es (...) un conocimiento mediante imágenes, las cuales, además, se orientan tan a menudo en el mismo sentido que nos hacen pensar seriamente en cierta unidad universal de la fantasía humana, por encima de las diferencias idiomáticas, étnicas o culturales'.
} 
them. My research visits at Lund University have been carried out with the support from several institutions (the Romanian Academy, the Royal Swedish Academy of Letters, History and Antiquities, and the 'Eugen Lozovan' Foundation - Copenhagen) to whom I want to render my thanks. Finally, I thank the two anonymous reviewers for their comments on an earlier version of this article.

\section{REFERENCES}

Barcelona, A. (2002). Metaphor and Metonymy at the Crossroads: A Cognitive Perspective. Berlin: Mouton de Gruyter.

Borcilă, M. (1997). The metaphoric model in poetic texts. In Péntek, J. (ed.), Text şi stil, Text and Syle, Szöveg és stílus (97-104). Cluj-Napoca: Presa Universitară.

Borcilă, M. (2002). Eugeniu Coşeriu, fondator al lingvisticii ca ştiinţă a culturii. In Popa, Gh., Şleahtiţchi, M. \& Leahu, N. (eds.), Un lingvist pentru secolul XXI (31-48). Chişinău: Ştiinţa.

Borcilă, M. (2003). Lingvistica integrală şi fundamentele metaforologiei. Dacoromania, Serie nouă, VII-VIII (2002-2003): 47-77.

Borcilă, M. (forthcoming). Bringing Coseriu home: Reflections on the fate of his legacy in our changing world. In Bojoga E., Vîlcu, C., Vîlcu, D., Boc. O. (eds.), Proceedings of the Second International Congress 'Eugenio Coseriu. Coseriu: Contemporary Perspectives', Cluj-Napoca, Romania, 23-25 September 2009. Cluj-Napoca: Presa Universitară.

Clark, A. (1999). An embodied cognitive science? Trends in Cognitive Science, 3(9): 345-351.

Coseriu, E. (1967). Teoría del lenguaje y lingüística general. Cinco estudios. Madrid: Editorial Gredos.

Coseriu, E. (1967 [1954]). Forma y sustancia en los sonidos del lenguaje. In Coseriu, E., Teoría del lenguaje y lingüística general. Cinco estudios (115-234). Madrid: Editorial Gredos.

Coseriu, E. (1967 [1956]). Determinación y entorno. In Coseriu, E., Teoría del lenguaje y lingüística general. Cinco estudios. Madrid: Editorial Gredos.

Coseriu, E. (1972). Die Geschichte der Sprachphilosophie von der Antike bis zur Gegenwart. Eine Übersicht. Teil II: Von Leibniz bis Rousseau. Tübingen, Germany: Gunter Narr Verlag.

Coseriu, E. (1981). Textlinguistik. Eine Einführung. Tübingen, Germany: Gunter Narr Verlag.

Coseriu, E. (1985 [1952]). La creación metaforica en el lenguaje. In Coseriu, E., El hombre y su lenguaje. Estudios de teoría y metodología lingüística (66-103). Madrid: Editorial Gredos.

Coseriu, E. (1985). Linguistic competence: What is it really? The Modern Language Review, 80(4): XXV-XXXV.

Coseriu, E. (1987 [1978]). Gramática, semántica, universales. Estudio de lingüística funcional. Madrid: Editorial Gredos. 
Coseriu, E. (1988 [1979]). Humboldt und die moderne Sprachwissenschaft. In Albrect, J., Lüdke, J. \& Thun, H. (Hrsg.), Energeia und Ergon. Sprachliche Variation - Sprachgeschichte Sprachtypologie, Studia in honorem Eugenio Coseriu. Band I: Schriften von Eugenio Coseriu (1965-1987) (3-11). Tübingen, Germany: Gunter Narr Verlag.

Coseriu, E. (1988). Sprachkompetenz. Grundzüge der Theorie des Sprechens. Tübingen, Germany: Franke Verlag.

Coseriu, E. (1992a). Strukturelle und kognitive Semantik. Vorlesung WS 1989-1990, Nachschrift von Ulrike Maier und Heinrich Weber. Unveröffentliches Manuskript. Tübingen, Germany: Universität Tübingen.

Coseriu, E. (1992b). Zeichen, Symbol, Wort. In Borsche, T. \& Stegmaier, W. (Hrsg.), Zur Philosophie des Zeichens (3-27). Berlin: Mouton de Gruyter.

Coseriu, E. (2000 [1990]). Structural semantics and 'cognitive' semantics, Willems, K. \& Leuschner, T. (tr.). Logos and Language, 1 (1): 19-42.

Coseriu, E. (2000a). Prolusione. Orationis fundamenta: La preghiera come testo. In De Gennaro S.J., G. (ed.), I quattro universi di discurso. Atti del Congresso Internazionale 'Orationis Millennium', L'Aquila, 24-30 giugno 2000 (24-47). Vatican City: Libreria Editrice Vaticana.

Coseriu, E. (2000b). Bilancio provvisorio. I quattro universi di discorso. In De Gennaro S.J., G. (ed.), I quattro universi di discurso. Atti del Congresso Internazionale 'Orationis Millennium', L'Aquila, 24-30 giugno 2000 (524-532). Vatican City: Libreria Editrice Vaticana.

Coseriu, E. (2001 [1977]). L'homme et son langage. In Coseriu, E., L'homme et son langage (31-69). Louvain-Paris-Sterling: Edition Peeters.

Coseriu, E. (2001). Le langage: diacriticón tes ousías. Dix thèses à propos de l'essence du langage et du signifié. In Keller, D., Durafour, J. P., Bonnot, J. F. P. \& Stock, R. (eds.), Percevoir: Monde et langage. Invariance et variabilité du sens vécu (79-83). Brussels: Mardaga.

Coseriu, E. (2003). Geschichte der Sprachphilosophie. Von Anfänge bis Rousseau. Tübingen, Germany: Franke Verlag.

Coseriu, E. (forthcoming [1999]) Locul lingvisticii integrale în lingvistica actuală. In M. Borcilă (ed.), Eugeniu Coşeriu şi studiile integraliste. Bucureşti: Editura Academiei Române.

Cuenca, M. J. \& Hilferty, J. (1999). Introducción a la lingüística cognitiva. Barcelona: Editorial Ariel.

De Cuypere (2008). Limiting the Iconic: From the Metatheoretical Foundations to the Creative Possibilities of Iconicity in Language. Amsterdam: John Benjamins.

De Oliviera R.P. \& Bittencourt, R. de S. (2008). An interview with Mark Johnson and Tim Rohrer: From neurons to sociocultural situatedness. In Frank, R.M., Driven, R., Ziemke, T. \& Bernardez, E. (eds.), Body, Language and Mind. Vol. 2: Sociocultural Situatedness (21-52), Berlin: Mouton de Gruyter. 
Di Cesare, D. (1888). Die aristotelische Herkunft der Begriffe érgon und enérgeia in Wilhelm von Humboldts Sprachphilosophie. In Albrect, J., Lüdke, J. \& Thun, H. (Hrsg.), Energeia und Ergon. Sprachliche Variation - Sprachgeschichte - Sprachtypologie, Studia in honorem Eugenio Coseriu. Band II: Das sprachtheoretische Denken Eugenio Coserius in der Diskussion I (29-46). Tübingen, Germany: Gunter Narr Verlag.

Dodge, E. \& Lakoff G. (2005). Image schemas: From linguistic analysis to neural grounding. In Hampe, B. (ed.), From Perception to Meaning: Image Schemas in Cognitive Linguistics (57-91), Berlin: Mouton de Gruyter.

Evans, V. (2006). Lexical concepts, cognitive models and meaning construction. Cognitive Linguistics, 17(4): 491-534.

Faur, E. (forthcoming). The Conceptual Metaphor in Integral Semantics. In Bojoga E., Vîlcu, C., Vîlcu, D., Boc. O. (eds.), Proceedings of The Second International Congress "Eugenio Coseriu. Coseriu: Contemporary Perspectives", Cluj-Napoca, Romania, 23-25 September 2009. Cluj-Napoca: Presa Universitară.

Frank, R.M. (2008). Introduction: Sociocultural situatedness. In Frank, R.M., Driven, R., Ziemke, T. \& Bernardez, E. (eds.), Body, Language and Mind. Vol. 2: Sociocultural Situatedness) (1-18). Berlin: Mouton de Gruyter.

Frank, R.M., Driven, R., Ziemke, T. \& Bernardez, E. (2008). Body, Language and Mind. Vol. 2: Sociocultural Situatedness. Berlin: Mouton de Gruyter.

Gallagher, S. (2005). How the Body Shapes the Mind. Oxford: Oxford University Press.

Gallagher, S. \& Brøsted-Sørensen, J. (2006). Experimenting with phenomenology. Consciousness and Cognition, 15 (1): 119-134.

Gallese, V. \& Lakoff, G. (2005). The brain concepts: The role of the sensory-motor system in conceptual knowledge. Cognitive Neuropsychology, 22(3-4): 455-479.

Geeraerts, D. (1993). Vagueness's puzzles, polysemy's vagaries. Cognitive Linguistics, 4(3): 223-272.

Geeraerts, D. (1997). Diacronic Prototype Semantics. Oxford: Clarendon Press.

Geeraerts, D. (2000). Salience phenomena in the lexicon: A typology. In Albertazzi, L. (ed.), Meaning and Cognition: A Multidisciplinary Approach (79-103). Amsterdam: John Benjamins.

Geeraerts, D. (2010). Theories of Lexical Semantics. Oxford: Oxford University Press.

Gibbs, R.W., .Jr. (1994). The Poetics of Mind: Figurative Thought, Language and Understanding. Cambridge, UK: Cambridge University Press.

Gibbs, R.W., Jr. (1999). Taking metaphor out of our heads and putting it into the cultural world. In Gibbs, R.W., Jr. \& Steen, G. (eds.), Metaphor in Cognitive Linguistics (145-166). Amsterdam: John Benjamins.

Gibbs, R.W., Jr. (2003). Embodied experience and linguistic meaning. Brain and Language, 84(1): $1-15$. 
Haser, V. (2005). Metaphor, Metonymy, and Experientialist Philosophy: Challenging Cognitive Semantics. Berlin: Mouton de Gruyter.

Hampe, B. (2005). Introduction. In Hampe, B. (ed.), From Perception to Meaning: Image Schemas in Cognitive Linguistics (1-14). Berlin-New York: Mouton de Gruyter.

Hampe, B. (2005). From Perception to Meaning: Image Schemas in Cognitive Linguistics. Berlin: Mouton de Gruyter.

Harder, P. (2007). Cognitive Linguistics and Philosophy. In Geeraerts D. \& Cuyckens, H. (eds.), The Oxford Handbook in Cognitive Linguistics (1241-1265). Oxford: Oxford University Press.

Ikegami, T. \& Zlatev, J. (2007). From non-representational cognition to language. In Ziemke, T., Zlatev, J. \& Frank, R. (eds.), Body, Language and Mind. Vol. 1: Embodiment (241-283). Berlin: Mouton de Gruyter.

Itkonen, E. (2003). What is Language? A Study in the Philosophy of Linguistics. Turku, Finland: Turku University Press.

Itkonen, E. (2006). Three fallacies that recur in linguistic argumentation. Speech and Language, 26(4): 221-225

Itkonen, E. (2008). Concerning the role of consciousness in linguistics. Journal of Consciousness Studies, 15(6): 15-33.

Itkonen, E. (2009). The true nature of typological linguistics. In Zlatev, J., Andren, M., Falck, M.J. \& Lundmark, C. (eds.), Studies in Language and Cognition (19-30). Cambridge, UK: Cambridge Scholars Publishing.

Johnson, M. (1987). The Body in the Mind. The Bodily Basis of Meaning, Imagination and Reason. Chicago: The University of Chicago Press.

Kabatek, J. (2000). Einheitlichkeit der Bedeutung, Designat und Integrale Linguistic. In Staib, B. (Hg.), Linguistica romana et indiana. Festschrift für Wolf Dietrich zum 60. Geburtstag (187-205). Tübingen, Germany: Gunter Narr Verlag.

Kimmel, M. (2005). Culture regained: Situated and compound image schemas. In Hampe, B. (ed.), From Perception to Meaning: Image Schemas in Cognitive Linguistics (285-312). Berlin: Mouton de Gruyter.

Kimmel, M. (2008). Properties of cultural embodiment: Lessons from the anthropology of the body. In Frank, R.M., Driven, R., Ziemke, T. \& Bernardez, E. (eds.), Body, Language and Mind. Vol. 2: Sociocultural Situatedness (77-108). Berlin: Mouton de Gruyter.

Lakoff, G. (1987). Women, Fire and Dangerous Things: What Categories Reveal about the Mind. Chicago: The University of Chicago Press.

Lakoff, G. (2008). The Neural Theory of Metaphor. In Gibbs, R. (ed.), The Cambridge Handbook of Metaphor and Thought (17-39). Cambridge, UK: Cambridge University Press.

Lakoff, G. \& Johnson, M. (1999). Philosophy in the Flesh: The Embodied Mind and its Challenge to Western Thought. New York: Basic Books. 
Lakoff, G. \& Johnson, M. (2003 [1980]). Metaphors we Live By. Chicago: The University of Chicago Press.

Lakoff, G. \& Turner, M. (1989). More Than Cool Reason: A Field Guide to Poetic Metaphor. Chicago: University of Chicago Press.

Langacker, R.W. (1987). Foundations of Cognitive Grammar. Vol. I: Theoretical Prerequisites. Stanford: Stanford University Press.

Langacker, R.W. (1991). Foundations of Cognitive Grammar. Vol. 2: Descriptive Application. Stanford: Stanford University Press.

Laplace, C. (1994). Théorie du langage et théorie de la traduction: les concepts-clef de trois auteurs: Kade (Leipzig), Coseriu (Tübingen), Selskovitch (Paris). Paris: Didier Érudition.

Martinez del Castillo, J. (2003). La teoría del hablar, una teoría del conocimiento. Odisea, 3: 131-154.

Rakova, M. (2002). The philosophy of embodied realism: A high price to pay? Cognitive Linguistics, 13(3): 215-245.

Rastier, F. (1989). Sens et textualité. Paris: Hachette.

Sinha, C. (1999). Grounding, mapping and acts of meaning. In Janssen, T. \& Redeker, G. (eds.), Cognitive Linguistics: Foundations, Scope and Methodology (223-255). Berlin: Mouton de Gruyter.

Sinha, C. \& Rodríguez, C. (2008). Language and the signifying object: from convention to imagination. In Zlatev, J., Racine, T., Sinha, C. \& Itkonen, E. (eds.), The Shared Mind: Perspectives on Intersubjectivity (357-378). Amsterdam, John Benjamins.

Sonesson, G. (2001). From Semiosis to Ecology. On the theory of iconicity and its consequences for the ontology of the Lifeworld. VISIO. Thematic issue: Cultural cognition and space cognition, $\mathbf{6}(2): 85-110$.

Sonesson, G. (2006). The meaning of meaning in biology and cognitive science. Sign System Studies, 34 (1): 135-214.

Sonesson, G. (2007). From the meaning of embodiment to the embodiment of meaning: A study in phenomenological semiotics. In Ziemke, T., Zlatev, J. \& Frank, R. (eds.), Body, Language and Mind. Vol 1: Embodiment (85-128). Berlin: Mouton de Gruyter.

Sonesson, G. (2009). The View from Husserl's Lectern. Considerations on the Role of Phenomenology in Cognitive Semiotics. Cybernetics and Human Knowing, 16(3-4): 107-148.

Talmy, L. (2000). Toward a Cognitive Semantics. Cambridge, MA, USA: The MIT Press.

Taylor, J.R. (1999). Cognitive Semantics and structural semantics. In Blank, A. \& Koch, P. (eds.), Historical Semantics and Cognition (17-48). Berlin: Mouton de Gruyter.

Taylor, J.R. (2003). Polysemy's paradoxes. Language Sciences, 25(6): 637-655.

Thompson, E. (2007). Mind in Life: Biology, Phenomenology, and the Science of Mind. London: Belkarp Press. 
Tyler, A. \& Evans, V. (2001). Reconsidering prepositional polysemy networks: The case of over. Language, 77: 724-765.

Tyler, A. \& Evans, V. (2003). The case of over. In Nerlich, B., Todd, Z., Herman, V. \& Clarke, D.D. (eds.), Polysemy. Flexible Patterns of Meaning in Mind and Language (99-159). Berlin: Mouton de Gruyter.

Van der Gucht, F., Willems, K. \& De Cuypere, L. (2007). The iconicity of embodied meaning. Polysemy of spatial prepositions in the cognitive framework. Language Science, 29(6): 733-754.

Violi, P. (2000). Prototypicality, typicality, and context. In Albertazzi, L. (ed.), Meaning and Cognition: A Multidisciplinary Approach (103-122). Amsterdam: John Benjamins.

Violi, P. (2008). Beyond the body: Toward a full embodied semiosis. In Frank, R., Driven, R., Ziemke, T. \& Bernardez, E. (eds.), Body, Language and Mind. Vol. 2: Sociocultural Situatedness (53-77). Berlin: Mouton de Gruyter.

Vîlcu, C. (2010). Orizontul problematic al integralismului. Integralism şi fenomenologie (Volumul I). Cluj-Napoca, Romania: Argonaut \& Scriptor.

Willems, K. (2003). Eugenio Coseriu (1921-2002). Versuch einer Würdigung. Leuvense Bijdragen, 92: $1-25$.

Willems, K. (2011). Meaning and interpretation: The semiotic similarities and differences between cognitive grammar and European structural linguistics. Semiotica, 185(1-4): 1-50.

Yu, N. (2008a). The relationship between metaphor, body and culture. In Frank, R., Driven, R., Ziemke, T. \& Bernardez, E. (eds.), Body, Language and Mind. Volume 2: Sociocultural Situatedness (378-408). Berlin: Mouton de Gruyter.

Yu, N. (2008b). Metaphor from body and culture. In Gibbs, R.W., Jr. (ed.), The Cambridge Handbook of Metaphor and Thought (247-261). Cambridge, UK: Cambridge University Press.

Zahavi, D. (2001). Beyond Empathy: Phenomenological Approaches to Intersubjectivity. Journal of Consciousness Studies, 8(5-7): 151-167.

Zahavi, D. (2003). Husserl's Phenomenology. Stanford: Stanford University Press.

Zahavi, D. \& Gallagher, S. (2008). The Phenomenological Mind: An Introduction to Philosophy of Mind and Cognitive Science. London: Routledge.

Ziemke, T., Zlatev, J. \& Frank, R. (2007). Body, Language and Mind. Vol. 1: Embodiment. Berlin: Mouton de Gruyter.

Zinken, J., Hellsten, I \& Nerlich, B. (2008). Discourse metaphor. In Frank, R.M., Driven, R., Ziemke, T., \& Bernardez, E. (eds.), Body, Language and Mind. Vol. 2: Sociocultural Situatedness (363-386). Berlin: Mouton de Gruyter.

Zlatev, J. (2003). Meaning = Life (+ Culture). An outline of a unified biocultural theory of meaning. Evolution of Communication, 4(2): 253-296. 
Zlatev, J. (2005). What's in a schema? Bodily mimesis and the grounding of language. In Hampe, B. (ed.), From Perception to Meaning: Image Schemas in Cognitive Linguistics (313-343), Berlin: Mouton de Gruyter.

Zlatev, J. (2007). Language, embodiment and mimesis. In Ziemke, T., Zlatev, J. \& Frank, R. (eds.) Body, Language and Mind. Vol. 1: Embodiment (297-337). Berlin: Mouton de Gruyter.

Zlatev, J. (2008a). The dependence of language of consciousness. Journal of Consciousness Studies, 15(6): 34-62.

Zlatev, J. (2008b). The co-evolution of intersubjectivity and bodily mimesis. In Zlatev, J., Racine, T., Sinha, C. \& Itkonen, E. (eds.), The Shared Mind: Perspectives on Intersubjectivity (215-244), Amsterdam: John Benjamins.

Zlatev, J. (2009a). The semiotic hierarchy: Life, consciousness, signs and language. In Cognitive Semiotics. Special Issue: Anthroposemiotics vs. Biosemiotics, 4: 169-200.

Zlatev, J. (2009b). Levels of meaning, embodiment and communication. Cybernetics and Human Knowing, 14(3-4): 149-174.

Zlatev, J. (2010). Phenomenology and Cognitive Linguistics. In Schmicking, D. \& Gallagher, S. (eds.), Handbook of Phenomenology and Cognitive Sciences (415-446). Dordrecht-New York: Springer.

Zlatev, J. (2011). From cognitive to integral linguistics and back again. Intellectica, 56: 125-147.

Zlatev, J. (2012). Cognitive semiotics: An emerging field for the transdisciplinary study of meaning. Public Journal of Semiotics, 4(1): 2-24.

Zlatev, J., Racine, T., Sinha, C. \& Itkonen, E. (2008). The Shared Mind: Perspectives on Intersubjectivity. Amsterdam: John Benjamins. 